\title{
OLIVE OIL TOURISM: EXPLORING THE EXPERIENCE OF FOOD TOURISTS
}

\section{Sandra Barač Miftarević Srđan Mitrović}

https://doi.org/10.20867/tosee.05.48

\begin{abstract}
Purpose - Food tourism is becoming one of the most popular special interest tourism niches and is necessary for destinations to provide kind of experiences these types of customers will seek out. The study aims to test the experience quality framework in the context of food tourism to gain better understanding of who food tourist are and what is their perceived experience of a visit to an olive oil tasting room.

Methodology - Data was collected in July of 2018 at an Istrian olive oil tasting room using an onsite questionnaire consisting of questions regarding experience quality dimensions, outcomes, motivation and sociodemographic characteristics of the visitors. A total of 129 visitors participated in the survey. Descriptive and bivariate statistics were used to analyze the data.

Findings - Results showed that entertainment and education were the highest rated experience dimensions while the environment was the lowest rated dimension. Significant differences were found for male and female visitors and visitors with higher and average and lower than average income in regard to the environment and functional value dimensions. No significant differences in experience level were found in regard to employment, education or the motivations of the visitors.

Contribution - Theoretically, research results provide a multi-dimensional view of experience quality and validate network of constructs in the context of food tourism. The study also enhances the knowledge regarding food tourists through their experiences and in managerial terms allows stakeholders in food tourism to use the proposed dimensions to enhance the development and marketing strategies of their tourism niche.
\end{abstract}

Keywords food tourism, experience economy, olive oil tourism, visitor experience

\section{INTRODUCTION}

In recent years, tourists are increasingly emphasizing on the importance of food and culinary experiences when choosing a destination. Although the food service industry has always been part of the tourism experience, food tourism research is a relatively recent development. Food tourism applies to tourists and visitors who plan their trips in pursuance of unique and memorable culinary experiences of all kinds (UNWTO, 2012).

Food tourism is a relatively old concept, but it can be considered as an emerging trend (Fox, 2007) because worlds' gastronomy has been adapted and developed by chefs, managers and local gastronomic community with the idea to offer something new, different and authentic in an effort to build a particular image or identity of the territory (Millan-Vazquezde de la Torre, Arjona-Fuentes and Amador-Hildago, 2017). The importance of local flavors and novelty is extremely important as Sims (2009) noticed 
ToSEE - Tourism in Southern and Eastern Europe, Vol. 5, pp. 89-100, 2019

S. Barač Miftarević, S. Mitrović: OLIVE OIL TOURISM: EXPLORING THE EXPERIENCE OF FOOD ...

that a worldwide sense of alienation from contemporary food production exists among consumers.

Olive oil represents not only food, but it represents a touch of history, culture and tradition (Hillel, Velase and Shani, 2013; Ritzer, 1993; Richards, 2002). In learning about olive oil and the process of growing and production tourists are more involved, touched and more assertive to positive emotions (Fields, 2002). Recently, the potential of olive oil and related oil products has started to become apparent to tourist board of Istria as it could become one of the most popular special tourist products in Croatia, which is evidenced by their launch of the Istria Gourmet Project which is a part of the that provides information and drives individuals towards tasting rooms and olive groves around the peninsula (Istria Tourist Board, 2013).

A growing body of research has validated the relevance of the experiential view of consumer behavior to understanding special interest tourism such as wine and food tourism and, within this experiential view, the experience economy has emerged as a viable framework for understanding how to enhance the special interest tourism value chain planning and operations (Quadri-Felitti and Fiore, 2013). Current research on the food tourists' experiences has been scarce. Understanding tourist experiences are valuable in constructing marketable and publicly attractive identities of tourist destinations (Tong, Tong and Tam, 2016). Hence the purpose of the paper is to explore the experience of food tourist in the context of an olive oil tasting room within the experience economy framework. Additionally, the study aims to compare the experiential dimensions in regard to the visitor's socio-demographic characteristics in an effort to better understand profiles of food tourists.

The paper is organized as follows: first, the conceptual background of the research is presented, followed by research methodology and main research results. Finally, conclusions, implications and recommendations for future research are discussed.

\section{CONCEPTUAL BACKGROUND}

\subsection{Food Tourism}

Food tourism studies have emerged recently with a focus on food destinations, food tourists and hygiene issues, according to Lee and Scott (2015). Kivela and Crotts (2006) stated that local gastronomy can give added value to the destination by attracting a specific tourist to the destination. Local culture and historic heritage are integral parts of the food experience (Hillel, Velase and Shani, 2013.). Some researchers define food as an essential part of cultural tourism because of its tradition, lifestyle, heritage and history (Ritzer, 1993; Richards, 2002.). The tasting of food and the knowledge of the production process of the typical local food are starting to be considered tourism practices that allow the traveler to get in touch with the complex heritage of identity, lifestyle and tradition of the area (Barrera, 2006). 
ToSEE - Tourism in Southern and Eastern Europe, Vol. 5, pp. 89-100, 2019

S. Barač Miftarević, S. Mitrović: OLIVE OIL TOURISM: EXPLORING THE EXPERIENCE OF FOOD ...

Food with all its tastes, aromas and colors is a powerful tool to build memories and wake up the senses, so in this food experience tourist can feel, touch or taste a story and history behind it. Tourists wish to gain relief from physical tension and experience fresh, exhilarating environments. An opportunity to taste new and exotic foods meets these needs for physical well-being, by offering sensory perceptions involving taste, sight and smell (Fields 2002).

According to UNESCO (2013): "Eating together is the foundation of the cultural identity and continuity of communities throughout the Mediterranean basin. It is a moment of social exchange and communication, an affirmation and renewal of family, group or community identity".

\subsection{Olive Oil Tourism}

Croatia as a Mediterranean country should be known as olive oil producer since hundreds of Croatian farmers are cultivating olive trees and have been producing olive oil and olives for centuries. It is a part of history, heritage and traditional lifestyle as in other Mediterranean regions such as Spain and Italy (Hillel, Velase and Shani, 2013; Ritzer, 1993; Richards, 2002.) and a part Mediterranean diet that is even recognized as an intangible cultural heritage from UNESCO (2013). Montoya (2003) pointed out that a renowned local traditional of making olive oil and their inclusion in tourists' itineraries will not only help develop regions away from the coast but will help keep centuries old agricultural heritage alive. De Salvo, Hernandez-Mogollon, Di-Clemente and Calzati (2013) in their research described how the oil, as a strong identity element of national culture, can be associated with many socio-economic benefits, including, primarily, the development of a culinary tourism that contributes to the development of many initiatives, such as tourist, educational ones and events that encourage and support not only new social relations, but the creation of new local economic networks whose activity can also contribute to the generation of income of agricultural enterprises in rural areas.

According to the Istria Gourmet Guide (2018) there are 121 olive oil producers in the region. Many of these olive oil producers have recognized the full potential of olive oil and olive oil products, and they started opening the olive oil tasting rooms for a specific new type of tourists. Tasting rooms are offering new tourist products, not only physical surrounding where tourists can taste and buy olive oil, but can also have a learning and socializing experience. Some common additional offers in the tasting rooms along with various types of mono varietal and blended olive oils are wines, balsamic vinegars, handmade chocolates with olive oil flavors, natural olive cosmetics and handmade ceramics. Certain families and tasting rooms keep showrooms of their old tools for maintaining olive groves to bring a new level to the visit experience. Accommodation and hospitality services at the olive groves are present but not widely developed.

Olive oil tourism can be seen as a special interest tourism motivated by anything related to olive oil and the resources that are related to the cultivation of olives such as water, land, countryside, the culture or the climate among other things, its specific nature is making this a typical Mediterranean product (Lopez Galvez, Montes Tubio and Moreno Vega 2013). Millan-Vazquezde de la Torre, Arjona-Fuentes and Aamador-Hildago 
ToSEE - Tourism in Southern and Eastern Europe, Vol. 5, pp. 89-100, 2019

S. Barač Miftarević, S. Mitrović: OLIVE OIL TOURISM: EXPLORING THE EXPERIENCE OF FOOD ...

(2017) note that olive-oil tourists are people who dedicate certain holiday time to a place other than their habitual residence in order to study the culture underlying the olive and its oil. Olive oil tasting rooms are full of curious tourists, eager to know more about the production and use of olive oil in daily life. They are motivated by wide range of experiences they want to partake in as some of them want to learn, others want to enjoy the atmosphere while some just want to meet new like-minded people and perception of their olive oil tourism experience is influenced by their own physiological characteristics as well as by collective representations that the tourist destination consists of (Rivera, 2015).

According the Murgado (2013) the success of the olive oil tourism depends on the design and improvement of tourist product in order to create culinary tourist experiences that will attract high income tourist that will be loyal to the region and willing to advocate for the tourist product.

\subsection{Experience economy in tourism}

Recently customer experience has been a key concept in service research and management in fields such as services marketing, innovation and retailing (Jakkola, Helkkula and Aarikka-Stenroos, 2015). Concept of the "experience economy" suggests that experience can be seen as a form of economic offering creating a competitive advantage that is hard to imitate or replace. In their seminal work Pine and Gilmore (1998) claim that customers want an experience not just goods or services. They claim experience is more than the delivery of a service; it is about creating a memorable and unique event, called "staged experience", where the buyer is the guest and the seller is the provider where experience is an ultimate added value in the supply chain. They identified four dimensions of experiences: educational, escapism, entertainment and aesthetics. Their framework has since been researched in various tourism contexts such as B\&B (Oh, Fiore and Jeoung, 2007), cruise tourism (Hosany and Witham, 2009), wine tourism (Quadrri and Fiore, 2013) but no such effort was done in a context of olive oil tourism.

Experiences have been viewed as the nature of the tourism industry in many studies (Cohen, 1979; Quan and Wang, 2004; Uriely, 2005; Oh, Fiore and Jeoung, 2007), while the most important part of the tourism experience according to Stamboulis and Skayannis (2003) is visiting, seeing, learning, enjoying and living a different life in a different environment. McIntosh and Siggs (2005) found that tourism experience should be considered as unique, emotionally charged, and of high personal value. In the tourism context, the experience may be recognized as a key of success, innovation and competitiveness (Ellis and Rossman, 2008).

Similar to how researchers have suggested and managers in wine tourism have developed the wine tourism experience the olive oil tourism experience should be offered in many ways such as visiting olive groves, olive oil factories, olive oil festivals or tasting rooms (Bruwer, 2003) as it has been underlined by many researchers that creation of "extraordinary" customer experiences is necessary as a part of the strategy to bring value to the consumer and foster satisfaction, loyalty and positive word of mouth. (Pine and Gilmore, 1998; Bolton et al., 2014). 
ToSEE - Tourism in Southern and Eastern Europe, Vol. 5, pp. 89-100, 2019

S. Barač Miftarević, S. Mitrović: OLIVE OIL TOURISM: EXPLORING THE EXPERIENCE OF FOOD ...

\section{RESEARCH METODOLOGY}

The present research aimed to identify and measure experience quality and experience outcome dimensions in context of a visit to an olive oil tasting room.

Both functional and affective components of experience were considered to better define experience quality dimensions (Sandstrom et al., 2008). Accordingly, research instrument was designed to measure six experience quality constructs: learning, entertainment, service providers, environment, functional value with a total of 21 items while experience outcomes were measured with two constructs: satisfaction and loyalty with a total of 8 items. The items were derived from previous experience economy research and adopted to fit the study setting. All items except the questions regarding visitor demographics and motivations employed a 7-point Likert scale with values: 1 strongly disagree, 7 - strongly agree.

Table 1: Experience quality dimensions

\begin{tabular}{|l|l|}
\hline Dimensions: & Researchers: \\
\hline Environment & $\begin{array}{l}\text { Chang and Horng 2010, Kim, Knutson } \\
\text { and Beck 2011 }\end{array}$ \\
\hline Service Providers & $\begin{array}{l}\text { Chang and Horng 2010, Klaus and } \\
\text { Maklan 2012 }\end{array}$ \\
\hline Learning & $\begin{array}{l}\text { Chang and Horng 2010, Fernandes and } \\
\text { Cruz 2016 }\end{array}$ \\
\hline Entertainment & Fernandes and Cruz 2016 \\
\hline Functional Value & Kim Knutson and Beck 2011 \\
\hline Loyalty & Kim Knutson and Beck 2011 \\
\hline Satisfaction & Kim Knutson and Beck 2011 \\
\hline
\end{tabular}

Source: Authors

Data was collected using a self-administered questionnaire handed out to visitors in an olive oil tasting room in Istria. Researchers visited the tasting room on three weekends during July 2018 and would survey both groups or individuals that had scheduled appointments on the days. Two larger groups of 43 Americans and 26 Scandinavian people were surveyed while the rest of the sample consisted of individual visitors that came to the tasting room either by appointment or were walk in customers.

Tasting program consisted of a walkthrough trough the production facilities in which visitors were informed on the methods used to produces olive oil, were introduced to the brand story, and were guided through a sensory panel to educate them about organoleptic and chemical attributes of the tasting rooms olive oil.

Visitors were surveyed on their experience after the tasting program was finished by the olive oil producer with the assistance of their staff and students that have been given detailed instructions on how to brief the respondents on the purpose of the research. After checking the questionnaires for missing data necessary corrections were made while the visitors were still present and total of 129 usable questionnaires were collected. 
ToSEE - Tourism in Southern and Eastern Europe, Vol. 5, pp. 89-100, 2019

S. Barač Miftarević, S. Mitrović: OLIVE OIL TOURISM: EXPLORING THE EXPERIENCE OF FOOD ...

Descriptive and bivariate statistical analysis were used to analyze the collected data using SPSS 23.0 software.

\section{RESEARCH RESULTS}

The sample consisted of 129 respondents, mostly females $(61.5 \%)$ predominantly from USA (33.6\%) as well as from Australia (15.6\%), Scandinavian countries (15.6\%) and UK $(11.7 \%)$. Sample consisted of visitors from 9 more countries but with the exception of Italy $(7,03 \%)$ no other country had more than $1.5 \%$ of the sample which includes Croatia, Slovenia, Austria, Germany, France, Macedonia, Hungary and Serbia.

Most of the respondents were married (54.6\%), employed (61.5\%), college or higher level of education $(66.8 \%)$ and higher than average income level $(63.8 \%)$. Approximate average age of the visitor was 41 years and their most common motivations for attending the olive oil tasting were to taste $(19.4 \%)$ and buy olive oil (17.1\%).

Table 2: Socio-demographic characteristics of respondents $(\mathbf{N}=129)$

\begin{tabular}{|c|c|c|c|}
\hline \multirow{2}{*}{ Variables and characteristics } & & \multicolumn{2}{|c|}{ Respondents } \\
\hline & & Frequency & Percentage \\
\hline \multirow[t]{5}{*}{ Country } & UK & 15 & 11.71 \\
\hline & USA & 43 & 33.59 \\
\hline & Australia & 20 & 15.62 \\
\hline & $\begin{array}{l}\text { Scandinavia (Finland, } \\
\text { Norway, Sweden, } \\
\text { Denmark) }\end{array}$ & 26 & 20.31 \\
\hline & Other & 24 & 18.75 \\
\hline \multirow[t]{4}{*}{ Age } & $20-30$ & 47 & 36.71 \\
\hline & $30-40$ & 26 & 20.31 \\
\hline & $40-50$ & 14 & 10.94 \\
\hline & $>50$ & 41 & 32.03 \\
\hline \multirow[t]{2}{*}{ Sex } & Male & 49 & 37.7 \\
\hline & Female & 80 & 61.5 \\
\hline \multirow[t]{2}{*}{ Marital Status } & Married & 71 & 54.6 \\
\hline & Single & 54 & 41.5 \\
\hline \multirow[t]{5}{*}{ Employment } & Employed & 80 & 61.5 \\
\hline & Self-employed & 20 & 15.4 \\
\hline & Retired & 12 & 9.2 \\
\hline & Unemployed & 10 & 7.7 \\
\hline & Other (student etc.) & 7 & 5.4 \\
\hline \multirow[t]{4}{*}{ Education } & High School & 25 & 19.2 \\
\hline & College/University & 35 & 29.9 \\
\hline & Post-Graduate & 48 & 36.9 \\
\hline & Other & 11 & 8.5 \\
\hline \multirow[t]{2}{*}{ Income } & Higher than average & 83 & 63.8 \\
\hline & Lower than average & 44 & 33.8 \\
\hline
\end{tabular}


ToSEE - Tourism in Southern and Eastern Europe, Vol. 5, pp. 89-100, 2019

S. Barač Miftarević, S. Mitrović: OLIVE OIL TOURISM: EXPLORING THE EXPERIENCE OF FOOD ...

\begin{tabular}{|c|c|c|c|}
\hline \multirow[b]{2}{*}{ Variables and characteristics } & & \multicolumn{2}{|c|}{ Respondents } \\
\hline & & Frequency & Percentage \\
\hline \multirow{9}{*}{ Motivation to visit } & Tasting olive oil & 25 & 19.4 \\
\hline & Buying olive oil & 22 & 17.1 \\
\hline & $\begin{array}{l}\text { Learning about olive } \\
\text { oil }\end{array}$ & 13 & 10.1 \\
\hline & $\begin{array}{l}\text { Experiencing the } \\
\text { atmosphere at the } \\
\text { tasting }\end{array}$ & 12 & 9.3 \\
\hline & $\begin{array}{l}\text { Finding unique olive } \\
\text { oils }\end{array}$ & 10 & 7.8 \\
\hline & Socializing & 17 & 13.2 \\
\hline & Meet the producers & 11 & 8.5 \\
\hline & $\begin{array}{l}\text { Having a relaxing day } \\
\text { out }\end{array}$ & 6 & 4.7 \\
\hline & $\begin{array}{l}\text { To enjoy the rural } \\
\text { setting }\end{array}$ & 13 & 10.1 \\
\hline \multirow[t]{3}{*}{ Accommodation } & Hotel & 43 & 33.1 \\
\hline & $\begin{array}{l}\text { Private } \\
\text { accommodation }\end{array}$ & 45 & 34.6 \\
\hline & Camping \& other & 41 & 31.5 \\
\hline
\end{tabular}

Source: Authors

Table 3 shows the results of descriptive statistical analysis, which was used to examine the olive oil tasting room experience. Experience quality attributes ranged from 1 (very low perception) to 7 (very high perception). Results as shown in the table indicate mean scores of visitor's perceptions range from 4.63 to 6.62 . The item with the lowest mean score is "The atmosphere of the tasting room has an impact on my state-of-mind" (4.63) while the item with the highest mean score is "Interacting with service providers makes me feel that I'm treated with respect" (6.62). The overall mean score for experience quality constructs was 6.2 which suggest a relatively high perception of experience quality. The environment was the lowest rated experience quality construct with a mean score of 5.23 while the highest rated experience quality construct was learning with a mean score of 6.51 which suggests that food tourism and activities such as olive oil tastings can serve as an educational platform for future customers of premium local products such as olive oil and has a layered importance for the region beyond showcasing the scenery of the agricultural and rural area.

\section{Table 3: Results of descriptive analysis $(\mathbf{N}=129)$}

\begin{tabular}{|l|l|l|}
\hline Dimension/Items & Mean & SD \\
\hline Environment & $\mathbf{5 . 2 3}$ & $\mathbf{0 . 8 6 5}$ \\
\hline The environment of the tasting room is enjoyable. & 5.55 & 0.821 \\
\hline The environment of the tasting room is stimulating to the senses. & 5.23 & 0.954 \\
\hline I am surprised with the tasting room environment. & 4.63 & 1.523 \\
\hline $\begin{array}{l}\text { The atmosphere of the tasting room has an impact on my state-of- } \\
\text { mind. }\end{array}$ & 4.86 & 1.255 \\
\hline Service providers & $\mathbf{6 . 4 3}$ & $\mathbf{0 . 8 4 3}$ \\
\hline $\begin{array}{l}\text { Service employees of the tasting room serve me friendly and } \\
\text { kindly. }\end{array}$ & 6.55 & 0.893 \\
\hline The people at the tasting room have good interpersonal skills. & 6.47 & 1.186 \\
\hline
\end{tabular}


ToSEE - Tourism in Southern and Eastern Europe, Vol. 5, pp. 89-100, 2019 S. Barač Miftarević, S. Mitrović: OLIVE OIL TOURISM: EXPLORING THE EXPERIENCE OF FOOD ...

\begin{tabular}{|c|c|c|}
\hline Dimension/Items & Mean & SD \\
\hline $\begin{array}{l}\text { Interacting with service providers makes me feel that I'm treated } \\
\text { with respect. }\end{array}$ & 6.62 & 0.868 \\
\hline Learning & 6.51 & 0.678 \\
\hline $\begin{array}{l}\text { The guides and brochures help me to learn and understand the } \\
\text { topics. }\end{array}$ & 6.16 & 1.102 \\
\hline I feel I have learned by attending this olive oil tasting & 6.33 & 1.106 \\
\hline $\begin{array}{l}\text { I've learned something new about olive oil after visiting this wine } \\
\text { cellar. }\end{array}$ & 6.6 & 0.888 \\
\hline Entertainment & 6.49 & 0.571 \\
\hline This is a tasting room where people can enjoy themselves. & 6.48 & 0.928 \\
\hline It is happy time when I visit this tasting room. & 6.51 & 0.945 \\
\hline Functional benefits & 6.47 & 0.603 \\
\hline The tasting room service is tailored to the visitors. & 6.33 & 1.084 \\
\hline The tasting room service level is of value to me. & 6.29 & $0-994$ \\
\hline Consistency of the service assures me a benefit. & 6.19 & 1.444 \\
\hline The visit to the tasting room is well organized. & 6.41 & 1.005 \\
\hline Trust & 6.36 & $\mathbf{0 . 8 2}$ \\
\hline The tasting room belongs to a safe and reputable brand. & 6.39 & 1.134 \\
\hline $\begin{array}{l}\text { My satisfaction with the tasting room products/services is the } \\
\text { management's most important concern. }\end{array}$ & 6.32 & 1.173 \\
\hline I'm confident in the cellar expertise. & 6.31 & 1.316 \\
\hline $\begin{array}{l}\text { My satisfaction with the brand is the management's most } \\
\text { important concern. }\end{array}$ & 6.16 & 1.253 \\
\hline Satisfaction & 5.97 & 1.106 \\
\hline $\begin{array}{l}\text { I feel good about coming to the tasting room for the offerings I'm } \\
\text { looking for. }\end{array}$ & 6.17 & 1.341 \\
\hline My feelings towards the tasting room are very positive. & 6.15 & 1.426 \\
\hline $\begin{array}{l}\text { The extent to which the tasting room has produced the best } \\
\text { possible outcome for me is satisfying. }\end{array}$ & 6.45 & 0.935 \\
\hline $\begin{array}{l}\text { Overall, I'm satisfied with the tasting room and the service they } \\
\text { provide. }\end{array}$ & 5.9 & 1.698 \\
\hline Loyalty & 5.83 & 1.068 \\
\hline $\begin{array}{l}\text { I consider visiting this tasting room as my first choice among } \\
\text { similar offers. }\end{array}$ & 5.81 & 1.589 \\
\hline $\begin{array}{l}\text { I would consider visiting this tasting room again in the next few } \\
\text { years. }\end{array}$ & 5.69 & 1.461 \\
\hline $\begin{array}{l}\text { I would recommend this tasting room to someone who seeks my } \\
\text { advice. }\end{array}$ & 6.18 & 1.391 \\
\hline $\begin{array}{l}\text { I would recommend the tasting room to family members and close } \\
\text { personal friends. }\end{array}$ & 6.29 & 1.269 \\
\hline I would speak positively of the tasting room to others. & 6.39 & 1.041 \\
\hline
\end{tabular}

Source: Authors

Overall mean score of experience quality outcomes was 5.9 with the satisfaction construct being higher (5.97) rated than the loyalty construct (5.83). The highest rated experience outcome item was "The extent to which the tasting room has produced the best possible outcome for me is satisfying" with the mean score 6.45 while the lowest rated item was "I would consider visiting this tasting room again in the next few years" with the mean score 5.69. Overall lower score for loyalty construct show the need to 
ToSEE - Tourism in Southern and Eastern Europe, Vol. 5, pp. 89-100, 2019

S. Barač Miftarević, S. Mitrović: OLIVE OIL TOURISM: EXPLORING THE EXPERIENCE OF FOOD ...

further develop the experiential aspect of the visit which could influence long term loyalty to the brand or region.

Bivariate statistics were used to compare the results according to the socio-demographic characteristics of the respondents. In regards to the visitors gender significant differences were found in the environment and functional benefits experience dimensions. Items that were rated higher by female respondents regarding environment experience were: "I am surprised by the tasting room environment" $(\mathrm{t}=-2.315 . \mathrm{df}=127 . \mathrm{p}<0.05)$ and "The atmosphere of the tasting room has an impact on my state of mind" $(\mathrm{t}=-2.534, \mathrm{df}=127$, $\mathrm{p}<0.05)$. In regard to the functional benefits experience females had a significantly higher mean score for items "Consistency of the service assures me a benefit" ( $\mathrm{t}=-3.444, \mathrm{df}=$ $81,82, \mathrm{p}<0.05)$ and "The visit to the tasting room is well organized" $(\mathrm{t}=-2.092, \mathrm{df}=82.84$, $\mathrm{p}<0.05$ ). Items "Interacting with service providers makes me feel like I'm treated with respect" $(\mathrm{t}=-3.108, \mathrm{df}=127 . \mathrm{p}<0.05)$ and "The guides and brochures provided help me understand the topics" $(\mathrm{t}=-2.792, \mathrm{df}=92,7 . \mathrm{p}<0.05)$ were both rated higher by female visitors but no significant difference was found in regard to the service providers or learning constructs which the items were a part of. No significant differences in mean scores for experience outcomes were found in regards to the visitor's gender.

In regard to the visitor's income visitors with higher than average income level had higher mean scores for items "The people at the tasting room have good interpersonal skills" ( $\mathrm{t}=2.758, \mathrm{df}=124 . \mathrm{p}<0.05)$ and "Interacting with service employees makes me feel like I'm treated with respect" $(\mathrm{t}=2.023, \mathrm{df}=124 . \mathrm{p}<0.05)$ but no significant difference was found in experience quality and experience outcome constructs. Also, no significant differences in mean scores for experience quality and outcomes was found in regard to visitors' employment, education or motivation.

\section{CONCLUSION}

The purpose of the research was to measure the perceived level of experience quality and related experience outcomes of visitors in an olive oil tasting room. Food tourism, and especially olive oil tourism as a new concept remains relatively understudied and calls for further research in an effort to understand the food tourists' motivations, experiences and post consumption evaluations. Theoretically, research results provide a multidimensional view of experience quality and validate the network of the constructs in the context of food tourism.

Overall experience quality with olive oil tourism offer seems relatively high with entertainment and learning being the highest rated experience dimensions which falls in line with stated primary motivations of tasting and learning about olive oil as well as socializing. Lowest rated experience dimension was environment which suggest that managers of the tasting room should consider benchmarking their facilities to more developed regions that engage in olive oil tourism activities and adapt their existing models to include a scenic overview of the olive fields or the surrounding rural area to enhance the visitors environment experience and possibly affect loyalty which, as results showed, was rated lower than satisfaction and overall experience quality. A more attractive surrounding where the olive oil tasting can be held could lead to more people 
ToSEE - Tourism in Southern and Eastern Europe, Vol. 5, pp. 89-100, 2019

S. Barač Miftarević, S. Mitrović: OLIVE OIL TOURISM: EXPLORING THE EXPERIENCE OF FOOD ...

developing an intention to return to the tasting room. There seem to be certain differences in regard to visitor's socio-demographic characteristics in perception of experience quality and outcomes however, those differences are marginal and further research should focus on different methodology such as cluster analysis to try to better describe the visitors. Additionally, further research should employ methods such a correlation and structural modeling to better understand the relationship and effect that experience quality dimensions have on relevant marketing outcomes.

This study enhances the knowledge regarding food tourists in Istrian region and in managerial terms, allows businesses and organizations in food tourism such as olive oil producers, travel agents and tourist boards to use these results to improve the overall experience quality of food tourism through a better understanding of its dimensions and through developing experience dimensions that are strongly associated with outcomes such as satisfaction and loyalty in an effort to improve the effectiveness of marketing strategies for the segment of food tourism.

A limitation of this study is that it focuses on one particular olive oil tasting room, short period of time, region and narrow customer sample. Further research across more tasting rooms and in different regions should cross-validate our research to increase the study's generalizability and could be extended to include other experience quality dimensions and outcomes.

\section{REFERENCES}

Barrera, E. (2006), Rutas alimentarias: Una estrategia cultural para el desarrollo rural mexicano. Consejo para la cultura y artes de México, México.

Bolton, R.N., Gustafsson, A., Mc-Coll Kennedy, J., Sirianni, N.J. and Tse, D. (2014) "Small details that make big differences, a radical approach to consumption experience as a firm's differentiating strategy", Journal of Service Management, Vol. 25, No. 2, pp. 253-274 https://doi.org/10.1108/JOSM-012014-0034

Bruwer, J. (2003), "South African wine routes: Some perspective on the wine tourism industry's structural dimensions and wine tourism product", Tourism Management, Vol. 24, No. 2, pp. 423-435 https://doi.org/10.1016/S0261-5177(02)00105-X

Chang, T. and Horng, S. (2010), “Conceptualizing and measuring experience quality, the customer's perspective", The Service Industries Journal, Vol. 30, No. 14, pp. 2401-2419 https://doi.org/10.1080/02642060802629919

Cohen, E. (1979), “A phenomenology of tourist experiences”, Sociology, Vol. 13, No. 2, pp. 179-201 https://doi.org/10.1177\%2F003803857901300203

De Salvo, P., Hernández Mogollón, J.M., Di Clemente, E. and Calzati, V. (2013), “Territory, tourism and local products. The extra virgin oil's enhancement and promotion: a benchmarking Italy-Spain", Tourism and hospitality management, Vol. 19., No. 1, pp. 23-34.

Ellis, G.D. and Rossman, J.R. (2008), "Creating value for participants through experience staging: parks, recreation, and tourism in the experience industry", Journal of Park and Recreation Administration, Vol. 26, No. 4, pp. 1-20.

Fernandes, T. and Cruz, M. (2016), "Dimensions and outcomes of experience quality in tourism: The case of Port wine cellars", Journal of Retailing and Consumer Services, Vol. 31, pp. 371-379 https://doi.org/10.1016/j.jretconser.2016.05.002

Fields, K. (2002), “Demand for the gastronomic tourism product; motivational factors”, in Hjalager, A.M. and Richards, G. (Eds), Tourism and Gastronomic, Routledge, London and New York, pp. 36-50.

Fox, R. (2007), "Reinventing the gastronomic identity of Croatian tourist destinations", International Journal of Hospitality Management, Vol. 26, No. 3, pp. 546-559 https://doi.org/10.1016/j.ijhm.2006.03.001 
ToSEE - Tourism in Southern and Eastern Europe, Vol. 5, pp. 89-100, 2019

S. Barač Miftarević, S. Mitrović: OLIVE OIL TOURISM: EXPLORING THE EXPERIENCE OF FOOD ...

Hillel, D., Velase, Y. and Shani, A. (2013), "What makes a gastronomic destination attractive? Evidence from the Israeli Negev", Tourism Management, Vol. 36, pp. 200-209 https://doi.org/10.1016/j.tourman.2012.12.006

Hosany, S. and Witham, M. (2009), "Dimensions of cruisers' experiences, satisfaction and intention to recommend", Journal of Travel Research, Vol. 49, No. 3, pp. 351-64 https://doi.org/10.1177/0047287509346859

Istria Tourist Board (2013), Nova digitalna aplikacija za istarske gastro adute, viewed $25^{\text {th }}$ March 2019 , https://www.istra.hr/hr/business-information/istra-u-medijima/priopcenja/arhiva-2013/1956

Istria Gourmet (2017), Wine and gastronomy of Istria, viewed $25^{\text {th }}$ March 2019 http://www.istria-gourmet.com/.app/upl_files/IstraGourmet_2017-18.pdf

Jakkola, E., Helkkula, A. and Aarikka-Stenroos, L. (2015), "Understanding and advancing service experience co-creation”, Journal of Service Management, Vol. 26, No. 2, pp. 82-205 https://doi.org/10.1108/JOSM-02-2015-0045

Kim, S., Knutson, B. and Beck, J. (2011), "Development and testing of the Consumer Experience Index (CEI)", Managing Service Quality, Vol. 21, No. 2, pp. 112-32 https://doi.org/10.1108/09604521111113429

Kivela, J. and Crotts, J. (2006), "Tourism and gastronomy: gastronomy's influence on how tourists experience a destination", Journal of Hospitality \& Tourism Research, Vol. 30, No. 3, pp. 354-377 https://doi.org/10.1177\%2F1096348006286797

Klaus, P. and Maklan, S. (2012), "EXQ, a multiple-item scale for assessing service experience", Journal of Service Management, Vol. 23, No. 1, pp. 5-33 https://doi.org/10.1108/09564231211208952

Lee, K.H. and Scott, N. (2015), "Food tourism reviewed using the paradigm funnel approach “, Journal of Culinary Science \& Technology, Vol. 13, No. 2, pp. 95-115 https://doi.org/10.1080/15428052.2014.952480

López Galvez, Y., Montes Tubio, F., and Moreno Vega, A. (2013), "Patrimonio Industrial Oleícola", ACUPIS, Cordoba

McIntosh, A.J. and Siggs, A., (2005), “An exploration of the experiential nature of boutique accommodation “, Journal of Travel research, Vol. 44, No. 1, pp. 74-81 https://doi.org/10.1177/0047287505276593

Millán-Vazquezde de la Torre, M. G., Arjona-Fuentes, J. M. and Amador-Hidalgo, L. (2017)," Olive oil tourism: Promoting rural development in Andalusia (Spain)", Tourism Management Perspectives, Vol. 21, pp. 100-108 https://doi.org/10.1016/j.tmp.2016.12.003

Montoya. T. (2003), "La gastronomía tradicional en el turismo rural “, in Martínez, J.M. (Ed.), Historia de la Alimentación rural y tradicional: recetario de Almería, Almería, pp. 159-161.

Murgado, E.M. (2013), "Turning food in to a gastronomic experience: olive oil tourism ", Options Méditerranéennes, No. 106, pp. 97-109.

Oh, H., Fiore, A.M. and Jeoung, M. (2007)," Measuring experience economy concepts: Tourism applications “, Journal of Travel Research, Vol. 46, No. 2, pp. 119-132 https://doi.org/10.1177\%2F0047287507304039

Pine, B.J. II. and Gilmore, J.H., (1998), "Welcome to the experience economy", Harvard Business Review, Vol. 76, No. 4, pp. 97-105.

Quadri, D. and Fiore, A.M. (2013), "Destination loyalty, Effects of wine tourists' experiences, memories and satisfaction experiences", Tourism and Hospitality Research, Vol. 13, No. 1, pp. 47-62 https://doi.org/10.1177\%2F1467358413510017

Quan, S. and Wang, N. (2004), "Towards a structural model of the tourist experience, An illustration from food experiences in tourism”, Tourism Management, Vol. 25, No. 3, pp. 297-305 https://doi.org/10.1016/S0261-5177(03)00130-4

Richards, G. (2002), "Gastronomy: an essential ingredient in tourism production and consumption", in Hjalager, A.M. and Richards, G. (Eds), Tourism and Gastronomic, Routledge, London and New York, pp. 3-20.

Ritzer, G. (1993), The McDonaldization of society, Sage, London.

Rivera, M. (2015), “Turismo experiencial y gestión estratégica de recursos patrimoniales: un estudio exploratorio de percepción de productos turísticos en las Sierras Subbéticas cordobesas (Andalucía)", Scripta Nova: Revista electrónica de geografia y ciencias sociales, Vol. 19, No. 511 , pp. 1-34 http://dx.doi.org/10.1344/sn2015.19.15115

Sandstrom, S., Edvardsson, B., Kristensson, P. and Magnusson, P. (2008), "Value-in-use through service experience“, Management of Service Quality, Vol. 18, No. 2, pp. 112-26 http://dx.doi.org/10.1108/09604520810859184

Sims, R. (2009), "Food, place and authenticity: Local food and the sustainable tourism experience", Journal of Sustainable Tourism, Vol. 17, No. 3, pp. 321-336 https://doi.org/10.1080/09669580802359293 
ToSEE - Tourism in Southern and Eastern Europe, Vol. 5, pp. 89-100, 2019

S. Barač Miftarević, S. Mitrović: OLIVE OIL TOURISM: EXPLORING THE EXPERIENCE OF FOOD ...

Stamboulis, Y. and Skayannis, P. (2003), "Innovation strategies and technology for experience-based tourism", Tourism management, Vol. 24, No. 1, pp. 35-43 http://dx.doi.org/10.1016/S0261-5177(02)00047$\mathrm{X}$

Tong X.F., Tong. D.Y.K. and Tam, W.S. (2016), "Food Tourism: The Melaka Gastronomic Experience", Journal of Emerging Trends in Marketing and Management, Vol. 1, No. 1, pp. 237-246.

United Nations Educational, Scientific and Cultural organization UNESCO (2013), The Mediterranean diet, viewed $23^{\text {rd }}$ March 2019 https://ich.unesco.org/en/RL/mediterranean-diet-00884

Uriely, N. (2005), "The tourist experience, Conceptual developments “, Annals of Tourism Research, Vol. 32, No. 1, pp. 199-216 https://doi.org/10.1016/j.annals.2004.07.008

World Tourism Organization UNWTO (2012), AM Vol. 4 Global report on food tourism, viewed $5^{\text {th }}$ January 2019 http://www2.unwto.org/publication/unwto-am-report-vol-4-global-report-food-tourism

Sandra Barač Miftarević, Phd Student

University or Rijeka

Faculty of Tourism and Hospitality Management

Istarska 4, Bale, Croatia

Phone: +385992664552

E-mail: sbaracmi@gmail.com

Srđan Mitrović, Phd Student

University or Rijeka

Faculty of Tourism and Hospitality Management

Slavonska 1, Split, Croatia

Phone: +385913322101

E-mail: mitrovic.srdan@gmail.com 